\title{
Electrocautery Versus Scalpel Scalp Skin Incisions
}

\author{
AYMAN M. ISMAIL, M.D.* and MOHAMMAD WAHEED EL-ANWAR, M.D.** \\ The Departments of Neurosurgery* and Otorhinolaryngology-Head \& Neck Surgery**, Faculty of Medicine, \\ Zagazig University, Egypt
}

\begin{abstract}
Background: Scalp skin incisions have routinely been perfumed with scalpel. Recently, there is a shift to electrocautery skin incision. But, questions about bad scars, wound healing and sequels on hair growth limits its popularity.

Aim of Study: The aim of current study was to compare the diathermy versus scalpel skin incision for elective cranial incisions with regards to post-operative pain, post-operative wound infection and wound healing and hair regrowth.

Patients and Methods: This prospective comparative study was conducted on 42 patients. 21 patients underwent diathermy incision (diathermy group) that was compared with 21 scalpel incision patients (scalpel group). Pain that was assessed by visual analogue scale, feasibility, postoperative infection rate and hair regrowth were assessed at 3 months postoperatively and compared between both groups.

Results: Electrocautery incisions were clearly easier with less bleeding and shorter operative time. Electraucautery showed significantly less post-operative pain $(p<0.05)$. Postoperative infection rate, scar and hair regrowth showed comparable results in both the groups $(p>0.05)$. No complication was reported with both techniques.
\end{abstract}

Conclusion: Diathermy scalp incisions are easier, faster, and less painful than scalpel incision with comparable results as regard scar and hair regrowth.

Key Words: Electrocautery - Scalpel - Scalp - Frontal sinus fracture.

\section{Introduction}

SURGICAL skin incisions are usually performed with scalpel that usually leads to skin bleeding that obscure the operating field increasing operative time. Diathermy represents an alternative that is mainly utilized for skin incision, tissue dissection and hemostasis [1]. However, questions about excess scars, wound healing and sequels on hair growth limits popularity of the diathermy scalp incisions

Correspondence to: Dr. Ayman M. Ismail, E-Mail: aymanmismael@.gmail.com
[2,3]. Recent electrosurgical units can deliver pure sinusoidal currents improved its quality and safety to gain the advantages of proper hemostasis, rapid dissection, and less operative blood loss $[4,5]$. Few studies had compared electrocautery and scalpel incision in the scalp [6,7]. Taking consideration that in the scalp, hair growth is an important factor that should be considered.

Therefore, The aim of the current study was to compare the diathermy with scalpel skin incision for elective cranial incisions with regards to postoperative pain, post-operative wound infection, scar character and wound healing and hair regrowth.

\section{Patients and Methods}

Forty two patients were included in the current prospective study at Zagazig University Hospitals, Zagazig, Egypt in the period between January 2016 and September 2018. Patients who were randomly assigned to 2 equal groups; 21 patients underwent diathermy incision (diathermy group) that was compared with 21 scalpel incision patients (scalpel group). Informed written consents were obtained from the patients and approval from the Zagazig University review board (IRB) was taken. Patients with previous scalp scars or lacerations, immunecompromised patients, and patients with pacemaker device were excluded from the study. The following parameters (feasibility, operative time, postoperative pain, post-operative wound infection, scar character, wound healing and hair regrowth and complication) were recorded, tabulated, and analyzed.

\section{Operative technique:}

All patients were performed under general anesthesia and the scalp was scrubbed and draped. In diathermy group, conventional electrocautery (Conmed Sabre 2400 electrocautery machine) was used. Active electrode was insulated throughout 
its length to avoid unneeded heat effect except at its distal cutting edge. Cutting mode was used to incise the skin while coagulation mode completes other scalp layers up to pericardium. The standard diathermy blade tip was used. Bipolar electrocautery was used for hemostasis when needed. To avert the skin edges away during cutting, mild traction was applied to either side of the skin incision. Therefore, onlythe tip of the diathermy electrode came in contact with the proposed incision line, and did not retouch the skin edges, so preventing resultant charring of the tissues.

In scalpel group, scalpel was used to incise the skin and other scalp layers till the galea.

In all cases, after finishing surgery, the galea was closed with 3.0 vicryl sutures and the skin edges were opposed with staples. The staples were removed at the 7 th postoperative day. Wound complications during the operation or up to 6 months follow-up were recorded. Wound infection was defined as the pus discharge from the wound [7] The post-operative pain was evaluated at the 1 st 2 nd and 3 rd post-operative days at a fixed time utilizing the visual analogue scale that was represented by a straight line measuring 10 scoring, the extremes of which corresponded to no pain at lower end and worst pain at the higher end [8]. Operative time for incision was calculated from begin skin incision till reaching the galea.

Collected data were statistically compared using tests from the SPSS program version 17 (Chicago, Illinois, USA). $p$-value $\leq 0.05$ is considered significant.

\section{Results}

42 cranial scalp incisions was done; 21 by diathermy (18 males and 3 females) and 21 by scalpel (17 males and 4 females). The patients' age ranged between $20-68$ years. The mean age for diathermy group was $44.2 \pm 3.22$ and themean age for scalpel group was $42.7 \pm 3.04$. Bothgroups were matched as regard age $(p=0.1302), \operatorname{sex}(p=$ $0.6792246)$ and type of approach $(p=0.92727973)$ (Tables 1,2). While in scalpel group, bleeding was significant and need skin clips to control, in diathermy group, little easily controllable bleeding or oozing were encountered and skin clips were not necessary. Pain score was significantly less in diathermy group $(p<0.00001)$ and in both group pain disappeared within two weeks after surgery. The mean operative time was significantly longer $(16.7 \neq 0.637)$ for scalpel group than diathermy group $(8.4 \neq 0.38, p<0.0001)$ (Table 2$)$. Wound scars were narrow without wound complication such as contracted wounds, hypertrophic scar after both groupsthroughout 6 months postoperative followup. There was also no noticeable alopecia around the wound in both groups at 6 months postoperatively. No infection was detected in both groups. No wound complication such as necrosis or infection occurred.

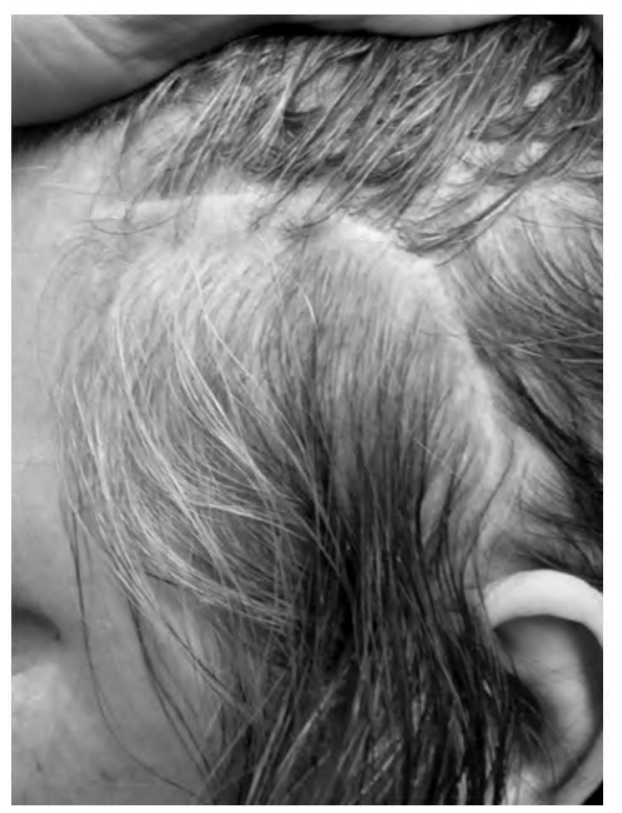

Fig. (1): Wound healing after scalpel scalp incision.

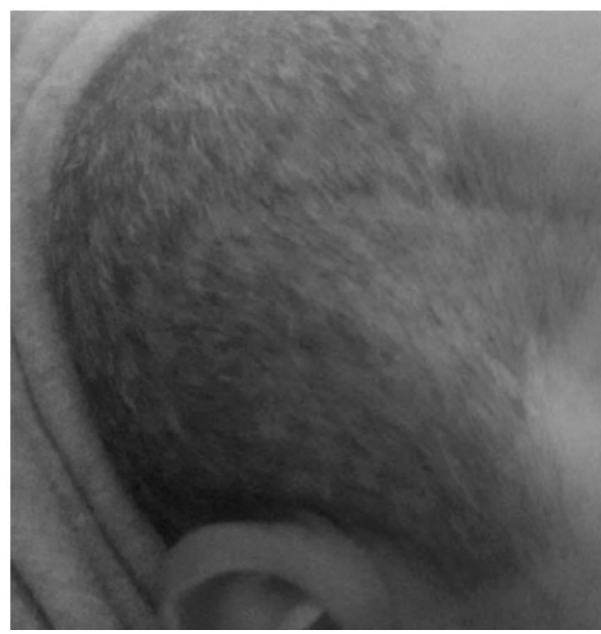

Fig. (2): Wound healing after electrocautery scalp incision.

Table (1): Preoperative data for scalpel versus diathermy groups.

\begin{tabular}{|c|c|c|c|c|}
\hline & $\begin{array}{l}\text { Scalpel } \\
\text { group }\end{array}$ & $\begin{array}{l}\text { Diathermy } \\
\text { group }\end{array}$ & Test & $\begin{array}{c}p- \\
\text { value }\end{array}$ \\
\hline \multicolumn{5}{|l|}{ Sex: } \\
\hline Male & $17(81 \%)$ & $3(14.3 \%)$ & $\mathrm{X}^{2}=0.171$ & 0.6792246 \\
\hline Female & $4(19 \%)$ & $3(14.3 \%)$ & & NS \\
\hline \multicolumn{5}{|l|}{ Age: } \\
\hline Range & $20-66$ & $21-68$ & $t=1.545$ & 0.1302 \\
\hline Mean \pm SD & $42.7 \pm 3.04$ & $44.2 \pm 3.22$ & & NS \\
\hline
\end{tabular}

$\mathrm{X}^{2}=$ Chi-square test. $\quad \mathrm{NS}=$ Non-significant 
Table (2): Operative data for scalpel versus diathermy groups.

\begin{tabular}{|c|c|c|c|c|}
\hline & $\begin{array}{l}\text { Scalpel } \\
\text { group }\end{array}$ & $\begin{array}{l}\text { Diathermy } \\
\text { group }\end{array}$ & Test & $\begin{array}{c}p^{-} \\
\text {value }\end{array}$ \\
\hline \multicolumn{5}{|c|}{ Types of approach: } \\
\hline Coronal & $12(50 \%)$ & $13(65 \%)$ & $X^{2}=0.151$ & 0.92727973 \\
\hline Pterional & $5(35 \%)$ & $4(15 \%)$ & & NS \\
\hline Retrosigmoid & $4(15 \%)$ & $4(15 \%)$ & & \\
\hline \multicolumn{5}{|l|}{$\begin{array}{l}\text { Postoperative } \\
\text { pain: }\end{array}$} \\
\hline $\begin{array}{l}\text { Median pain } \\
\text { scale }\end{array}$ & $5(85 \%)$ & $3(80 \%)$ & $\begin{array}{l}\text { Z-score }= \\
5.13816\end{array}$ & $\begin{array}{l}<0.00001 \\
S\end{array}$ \\
\hline \multicolumn{5}{|l|}{ Time of incision: } \\
\hline Mean & $\begin{array}{l}16.7 \# \\
0.637\end{array}$ & $8.4 \# 0.38$ & $t=51.2790$ & $\begin{array}{l}<0.0001 \\
S\end{array}$ \\
\hline Range & $10-19$ & $5-11$ & & \\
\hline
\end{tabular}

\section{Discussion}

The surgical use of electrocautery dates back to 1909 [9] later, in 1926, it was used in neurosurgery [10]. The reluctance to incise skin with electrocautery is partly attributable to concerns about the possible excessive scarring and poor wound healing. However, recently no difference was reported in wound complications between the cold scalpel and electrocautery [7].

Modern electrocautery equipment as that used in the current study that is commonly used nowadays in surgery has cutting and coagulation modes. Cutting mode produces a continuous output, while coagulation mode involves a pulsed output. The blend facility only functions when in cutting mode and allows a combination of cutting and coagulation to increase the haemostasis degree during cutting [8].

Several studies have investigated electrocautery skin incision mainly for abdominal or thoracic skin incisions that proved to be safely effective $[11,12]$ However very few studies were undertaken on diathermy usage in the scalp incision with no previous comparative study between cold scalpel and diathermy with its conventional electrode tip for scalp incisions was performed in cranial approaches.

In the current study, we did this comparative prospective study. We found that electrocautery did not increase the incidence of indurated wound margins, infection, and weakness of the wound cut and did not lead to wider peri-incisional alopecia area compared with the cold scalpel. It had been assumed that local tissue diathermy heating elevates the oxygen tension in the subcutaneous tissue, so improving wound resistance to infection [13]. More- over, we suggested that this increase oxygen tension will also help to enhance hair follicle support and support proper wound healing.

In addition, time taken during was significantly shorter and blood loss was less using diathermy than cold scalpel. We insured that following the well-known guidelines for use the electro cautery [14] is a must for safety of diathermy usage. The shorter operative time on diathermy use is mainly due to it hemostatic cutting with minimal bleeding and non-obscured operative field and no need for use of clips in the wound edges.

Thus, Electrocautery skin incision is safe procedure and effective with advantages of less operation times, little blood loss from the edges of skin incision and possible avoidance of skin edge necrosis or alopecia caused by skin clips. Therefore we recommend electrocautery skin incision for cranial approach and still investigation of its use in patients who supposed to have healing problem such as diabetic patients is needed.

\section{Conclusion:}

Diathermy scalp incisions are easier, faster, and less painful than scalpel incision with comparable results as regard scar and hair regrowth.

\section{Compliance with ethical standards:}

- Funding: No funding received.

- Conflict of Interest: The authors declare no conflict of interest.

- Ethical approval: Approval from the Zagazig University review board (IRB) was taken and all procedures performed in studies were in accordance with the ethical standards of the institutional research committee and with the 1964 Helsinki declaration and its later amendments.

- Informed consent: Informed written consents were obtained from the included patients.

\section{References}

1- SHAMIM M.: Diathermy vs. scalpel skin incisions in general surgery: Double-blind, randomized, clinical trial. World J. Surg., 33: 1594-9, 2009.

2- SOBALLE P.W., NIMBKAR N.V., HAYWARD I., NIELSEN T.B. and DRUCKER W.R.: Electric cautery lowers the contamination threshold for infection of laparotomies. Am. J Surg., 175: 263-6, 1998.

3- HUSSAIN S.A. and HUSSAIN S.: Incisions with knife or diathermy and postoperative pain. Br. J. Surg., 75: 1179-80, 1988.

4- CHALYA P.L., MCHEMBE M.D., MABULA J.B. and GILYOMA J.M.: Diathermy versus scalpel incision in elective midline laparotomy: A prospective randomized controlled clinical study. East. Cent. Afr. J. Surg., 18: 717,2013 
5- KUMAR V., TEWARI M. and SHUKLA H.S.: A comparative study of scalpel and surgical diathermy incision in elective operations of head and neck cancer. Indian J. Cancer., 48: 216-9, 2011.

6- SHEIKH B.: Safety and efficacy of electrocautery scalpel utilization for skin opening in Neurosurgery. British Journal of Neurosurgery, 18 (3): 268-272, 2004.

7- NITTA N.1, FUKAMI T. and NOZAKI K.: Electrocautery skin incision for neurosurgery procedures-technical note. Neurol. Med. Chir. (Tokyo)., 51 (1): 88-91, 2011.

8- RAGESH K.V., MAHENDRAN S. and MATHAD S. Outcome of skin incision by cautery versus steel scalpel in hernia surgery: A prospective cohort study at a tertiary medical college hospital in South India. Int. Surg. J., 4 (5): 1521-1524, 2017.

9- GARISON F.H. History of medicine. Philadelphia: WB Saunders Co., 1929.
10- FULTON J.: Harvey Cushing: The story of a great medical pioneer. Springfield: Charles C. Thomas Publisher, 1946.

11- ALLAN S.N., SPITZ L., VAN NOORT R. and BLACK M.M.: A comparativestudy of scalpel and electrosurgical incision on subsequentwound healing. J. Pediat. Surg., 17 (1): 52-4, 1982.

12- GROOT G. and CHAPPELL E.W. : Electrocautery used to create incisionsdoes not increase wound infection rate. Am. J. Surg., 167: 601-3, 1994.

13- CHRYSOS E., ATHANASAKIS E., ANTONAKAKIS S., XYNOS E. and ZORAS O.: A prospective study comparing diathermy and scalpel incisions in tensionfree inguinal hernioplasty. Am. Surg., 71: 326-9, 2005.

14- SIDDAIAH-SUBRAMANYA M., TIANG K.W. and NYANDOWE M.: Complications, implications, and prevention of electrosurgical injuries: Corner stone of diathermy use for junior surgical trainees. Surg. J. (N Y), 3 (4): e148-e153, 2017.

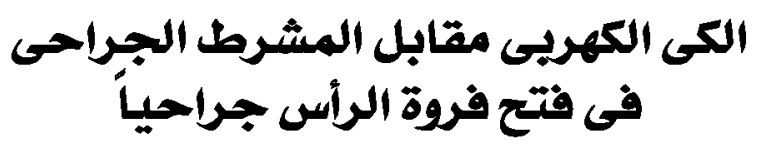

$$
\begin{aligned}
& \text { المقدمة: عادة ما يستخدم المشرط الجراحى لفتح فروة الرأس أثناء الجراحة ولكن حديثاً تم الجوء إلى طريقة الفتح بواسطة الكى الكهربي } \\
& \text { ولكن الخوف من أن تؤثر هذه الطريقة على إلتئام الجرحع أو تركها لندبات غير مستحبة حجم أنتشارها على نطاق واسع. } \\
& \text { الهدف: الهدف من هذه الدراسة هى إجراء مقارتة بين طريقة إستخدام الكى الكهربائى والقتح بواسطة المشرط الجراحى لفتع فروة الرأس }
\end{aligned}
$$

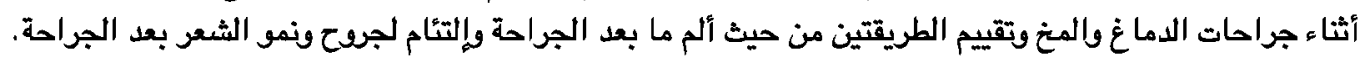

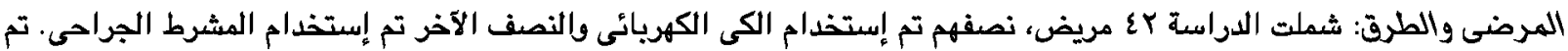

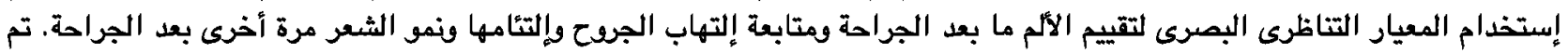

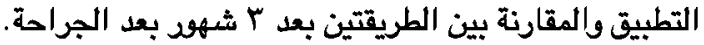

$$
\begin{aligned}
& \text { النتائج: إستخدام الكى الكهربائى كان أسهل فى وقت أقصر ونزف أقل أثناء الجراحة عن الطريقة التقليدية بواسطة المشرط. وكانت معدلات } \\
& \text { إلتهاب الجرح وتقييم الندبات ونمو الشعر متقاربة بين الطريقينين. } \\
& \text { الأستتاج: إستخدام الكى الكهربائى فى فتح فرة الرأس جراحياً أسهل، أسرع، أقل ألم مقارنة بإستخدام المشرط مع نتائج متقاربة }
\end{aligned}
$$

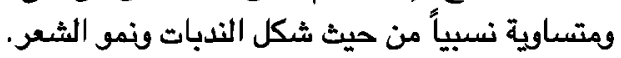

